\title{
AN EVALUATION OF AHMAD DAHLAN IMPACTING TO THE LEADERSHIP IN INDONESIA
}

\author{
Anton Sebastian 1) Stanley ${ }^{2)}$ \\ 1) Abdi Gusti Theological Seminary - Nganjuk \\ E-mail: anton@sttabdigusti.ac.id \\ 2) Abdi Gusti Theological Seminary - Nganjuk \\ E-mail: stanley@sttabdigusti.ac.id
}

\begin{abstract}
Ahmad Dahlan is the fourth child. Born in 1868 to a traditional Muslim family domiciled in Kauman, a religious village in Yogyakarta. The village is located just beside the Sultan Palace of Yogyakarta, and is a well-known village inhabited by Muslims. When he was a child, his name was Muhammad Darwisy. Upon returning from Mecca, he changed his name to Ahmad Dahlan. His father Kiai Haji Abu Bakar bin Haji Sulaiman, was the official Kotib of the Great Mosque of the Sultanate of Yogyakarta. His mother named Siti Aminah was the daughter of Religious Judge Kiai Haji Ibrahim. According to the biographers of Ahmad Dahlan, one of Dahlan's ancestors was the first and most famous guardian of Wali Songo, Maulana Malik Ibrahim. Even the Dutch report said he was Arabic. This report may be true because based on this genealogical background, which was strengthened by his interest in reform ideas, Ahmad Dahlan - before establishing his own organization joined Jamiat Kheir and later sent his son to study at the school the organization had founded. This paper aims to see to what extent the approach strategy and values used by Ahmad Dahlan to advance Islamic teachings? What is the Government's attitude towards what Ahmad Dahlan has done? Then, how is the author's critical evaluation of Ahmad Dahlan's approach to strategy to education in Indonesia? Application: challenge Indonesian national educators.
\end{abstract}

Keywords: Evaluation, Ahmad Dahlan, Educators Of Indonesia

\section{INTRODUCTION}

Ahmad Dahlan is indeed the type of person who works holistically. Not only does he give or view all problems with one side, but his whole life and all views are given to his work. With the presence of the name Maulana Ibrahim in the lineage of Muhammad Darwis, it can be said that he was born in a strong Islamic environment, given that Maulana Ibrahim's role as one of the Wali Songo was very large in the Islamization of Java Island. Muhammad Darwis did not study at the Gubernemen school, he received education, especially religious education from his 
own father. His intelligence and tenacity as a child of Kauman Village began to be proven because at the age of 8 he had successfully finished reading the Holy Quran and memorized 20 attributes of Allah. ${ }^{1}$ In 1890 he continued his higher education to Mecca, the center of teaching Islamic orthodoxy in the world. He is only 22 years old. He lived in the holy city for several years to study religious sciences. He was a student of Shaykh Ahmad Khatib (1855-1916), an Indonesianborn figure who at that time occupied the highest position in his mastery of the religious sciences in Mecca.

After his father died in 1896, Dahlan replaced him, namely as Kotib at the Great Mosque of Kauman Yogyakarta. In 1912 he founded Muhammadiyah, this name is the same as the previous religious school in Yogyakarta. And he died in 1923. It was recorded that in 1921, Muhammadiyah only had five branches. In 1922, the number had increased to 15 branches throughout Indonesia. Two years after Dahlan died, 1925, Muhammadiyah had established 23 branches and continued to grow rapidly

${ }^{1}$ Weinata Sairin, Gerakan Pembaruan Muhammadiyah (Jakarta: Sinar Harapan, 1995) 39. throughout Indonesia. By 1942, the number of branches had reached 1,275. ${ }^{2}$ We can see this when he has the idea of reforming Islamic teachings based in Yogyakarta, as follows:

\section{Character Approach Dahlan shows} everything character to his people and people outside his religion as an example. He is a person who is honest, loyal, open (democrat), and highly respects the views of others even though he has different religions. So that it is better for him to avoid arguments than later when someone's heart gets hurt. Abdul Munir Milkhan said:

The relevance of his views lies in his critical and open attitude towards the development of science and technology as well as his belief in the Koran along with his belief in the ability of human reason based on honesty and faith. This was not only proven by his willingness to adopt various patterns of social activities carried out by other people who at that time were included as infidels in the consciousness of the ummah but also his enthusiasm for seeking knowledge from various

\footnotetext{
${ }^{2}$ Hadikusuma, Matahari-matahari Muhammadiyah (Yogyakarta: Pesatuan, t.t.) 63-64.
} 
sources in the country and the Middle

East. M. Rusli Karim is of the opinion that Dahlan himself is known as a very democratic, open leader and highly appreciates intellectuals from any group. He himself did not abandon his thoughts in written form, because he was afraid that someday Muhammadiyah members would only stick to what he wrote without developing the initiative to seek the best for various aspects of Muslim life. Karim continued, saying: $\mathrm{He}$ is also very open to criticism and prioritizes dialogue. Not only between leaders of Islamic organizations but also among Christians. This climate allows Muhammadiyah to continue to be dynamic.

2. Creative and Harmonious Collaboration Approach Dahlan is of the view that attitudes that tend to be politically active are unrealistic choices. Therefore, during Dahlan's leadership, it was more emphasizing a creative and harmonious cooperative approach between the Dutch government and Muhammadiyah, so that both the Dutch and Muhammadiyah rulers benefit from this cooperation. The first is to benefit from a nonoppositional attitude; the second benefits from the attitude of the former in favor of its programs of religious reform.Alwi Shibab in his dissertation said: This is the factor that explains the Muhammadiyah can grow and develop in a period when no movement comparable to it can survive. His accommodative and cooperative demeanor had given him the flexibility necessary to survive, in a climate that was extremely hostile to indigenous nationalist movements.

3. The Love Peace and Tolerance Approach The Love, Peace and Tolerance approach has also colored her life very much. In solving all problems he tends to use the Win Win Solusion principle. For example, when he had to deal with Christians, Dahlan was more tolerant of missionary activities, especially during the early days of Muhammadiyah, which cannot be interpreted other than as an indication of Dahlan's realistic approach.Alwi Shibab says:

At these particular stages in his career, Dahlan emerged as a very mature person, very different from his youth as a rebellious kiai. His apparent peace-loving and tolerant attitude towards Christians meant a great deal to the establishment of a solid infrastructure for the continuation of his 
organization.

Dahlan's extraordinary success and influence, first, was due to his insight and optimism that reached far into the future. Second, it was caused by his attractive personality and hardness of heart. He never gave up in fighting for his aspirations and hopes. His realism and patience, deeply ingrained in his personality, enabled him to win the support of the Dutch government. A secret Dutch report stated that he was highly respected by the Dutch government. Dahlan is energetic, militant, intelligent and very orthodox, but at the same time also has a high sense of tolerance. One of the reports further states that as a person, and a person with a disposition and will that is rarely found in both the Indies and in Europe. In another report, a year before his death, Dahlan was still a wellliked figure. According to Schrike, even a Catholic missionary, Bakker one of Muhammadiyah's enemies - said that Dahlan was a tolerant man of Christians.

\section{Social Approach Social problems are} also used by Dahlan as an approach to his ideas (as well as himself) towards others. Dahlan really pays attention to the implementation of real charity in the midst of everyday life. Among the verses of the Koran that were very rich in his heart were Surah 107: 1-17:

Do you know people who reject religion? That is people rebuke orphans, and do not recommend feeding the poor. So it is bad for those who pray (that is) those who neglect their prayers, those who do riya, and are reluctant (to help with) useful things.

This is not just theory, but Dahlan also does it. One day he ordered his students to go around looking for the poor and to give them soap, clean clothes, food and drink and even stay in the homes of his students.

Likewise, when he replaced his father as Kotib at Mesjid Agung, for example. This designation was not solely due to conventional reasons, but because Dahlan had the broad religious insight required for the position. Weinata Sairin says: Ahmad Dahlan also used the implementation of his duties as Kotib to disseminate his thoughts to the public. His absence, honesty, and concern for social problems at that time made Ahmad Dahlan increasingly favored by many people so that he was nicknamed Kotib Amin, which means, trustworthy chaplain. 


\section{RESEARCH METHOD}

This research is a qualitative research which is literature study (library research) which uses books and other literature as the main object (Hadi, 1995: 3). The type of research used is qualitative, namely research that produces information in the form of notes and descriptive data contained in the text under study (Mantra, 2008: 30). With qualitative research, descriptive analysis is necessary. Method descriptive analysis provides a clear description and information.

\section{RESULTS AND DISCUSSION}

\section{The Government's Attitude Towards}

Ahmad Dahlan's Teaching Through Muhammadiyah Education

The Government's attitude towards what Dahlan was doing received support from the Government. As proof that the Government appreciates it is the President in Decree No. 675, dated December 27, 1961, has declared K.H. Ahmad Dahlan as a National Hero. The basics of determination are: K.H. Ahmad Dahlan made local educators aware of Indonesian Muslims that they were a colonized nation who still had to learn and do. K.H. Ahmad
Dahlan through the Muhammadiyah organization he founded gave pure Islamic education teachings; which demands progress, intelligence, and charity for society and people on the basis of faith and Islam. Muhammadiyah education has pioneered social efforts and educates the nation's educators who are needed for the progress of the nation, with Islamic teachings.

Muhammadiyah education through its women's organization, Aisyiah, has pioneered the revival of Indonesian women to get an education equal to that of men. Apart from Kyai Haji Ahmad Dahlan, his wife, who is often referred to as Nyai Dahlan, has been appointed by the Government as a National Education Hero because of her services in organizing, mobilizing and advancing the education of Indonesian women in various fields through the women's organization Aisyah.

\section{Critical Evaluation Towards Ahmad}

\section{Dahlan's Approach Strategy Toward}

\section{Educators In Indonesia}

Ahmad Dahlan's strategy of approach to education in Indonesia character approach, creative and harmonious cooperation, peace-loving and tolerance, and social - is a holistic approach. This section will critically evaluate these 
approaches for educators in Indonesia. National Character Education Approach

Dahlan's character education approach deserves to be respected and even used as a living example. He dared to make himself an open letter to anyone. He tries to be an educator who is loyal to his job as a teacher, is honest, accepts what other people think, and respects others indiscriminately.

Even though he was an exemplary educator but could not be compared to the perfect example of the Great Teacher Jesus Christ, Jesus also taught that believers live by His example. James P. Dretke said that educators must be witnesses of God (Isa. 43: 10,12; Luke 24:48; John 15:27; Acts 1: 8). But how? Educators must live honestly, brotherly, morally, and live in truth. God's Word is revealed to us so that we can live in His truth through the teachings of His Word. God's children are given the faith to witness to others. That testimony emerges from our hearts: honest, brotherly, moral, and truthful. This is what educators are told to say. Educators practice the values of God's love.

Do not let it be like Isaiah 17: 9 that: How treacherous a heart is, more treacherous than all things, whose heart is stony: who can know it? Because it is very important for Christians to train their hearts to witness honestly to God and their neighbors. Likewise, Dahlan has become a witness not only for educators in Indonesia. Educators who are Cooperative, Creative and Harmonious Cooperation by maintaining harmony is not something new. Since entering the years of Indonesian independence, educators on Christians, Islam and other religions also worked together to fight colonial rule. The results of this work are very good, for example, Christians who thought they were the collaborators of the Dutch or the colonial religion, and Islam was considered the Arabic religion, and finally they could accept each other as part of the big Indonesian family. Bambang Ruseno Utomo said that we must accept: A call to live and accept the reality of Indonesia as a plural society based on Pancasila. Indonesian society is very pluralistic, consisting of various ethnicities, languages, customs, cultures, religions and beliefs and Pancasila is the basis of society, nation and state. In a society like this there are several possibilities, namely clashes between groups with one another, erecting walls of separation and indifference to one another which ultimately leads to dividing and splitting the nation, or it can also influence and enrich one another.

Obviously, disintegration is a threat to the preservation of national unity and the development of the country towards a just and prosperous society based on Pancasila. 
Bambang Ruseno concluded that Indonesia's problem is how to make the educator community of the Indonesian nation realize harmony, harmony and balance, and avoid polarization. The pattern of living in harmony which is the root of Indonesian culture in all its positive and negative aspects can be seen from the expressions of Bhineka Tunggal Ika, klih sameka, loro loroning atunggil.

\section{Peace-loving and Tolerant}

\section{Educators Love peace}

The peace-loving approach has actually become a character for every religion. If a man is truly religious, then he must love peace. Bambang The word Islam comes from the word aslama, consisting of three Arabic consomans slm, meaning the religion of peace, a religion that teaches its adherents to actively surrender to the way of Allah in order to get peace in the world and the hereafter. Islam is a religion that longs for and loves peace. Christian-Catholicism teaches its adherents to follow Christ and Christians belong to Christ and must be involved in Christ's work to bring about peace. Where by His death and resurrection Christ has reconciled man to God, so that man can be at peace with himself, with others and with his environment. It is clear that Christian-Catholicism is a religion of peace, a religion that loves peace and is called to create peace. Christians are the ones who have received God's peace and are being processed towards lasting peace. Therefore, the life of a Christian cannot be other than trying to realize this peace. So, what Dahlan did to live in peace reflects the seriousness of the nation's educators in Indonesia. $\mathrm{He}$ is a person who is very devout to his religion. Not just being obedient, but he really understands the basic teachings of Islam. But the question is to what extent is Dahlan's love of peace? Is peace love temporary or eternal? For Augustine that what humans do is temporary peace. Even so, it is still done and the most important thing is to make eternal peace led by God where humans must obey God's rules, namely: humans must be able to live in God's love. Augustine says: Peace between man and God is the obedience of human faith to God's laws. Human-human peace is a command of harmony. Family peace is another family member is also an order of harmony. The peace of the citizen with the citizens of other countries is also an order of harmony. However, the peace associated with heaven is a perfect command by which people will live in harmony with God. 


\section{Tolerance}

Tolerance means tolerating a view that we actually do not agree with. Tolerance is a tool to achieve other goals, such as living in harmony. Tolerance is not a concept of love or justice. Tolerance is not something that is good in itself, but a tool for an end. So, even though it is not good for yourself, it is still done as long as it reaches the goal. This kind of approach was taken by Dahlan towards the Dutch Government and educators in Indonesia.

Dahlan tried to tolerate the views of other people or parties even though he did not agree with it. Herein lies Dahlan's success in approaching other parties. However, matters become difficult when applied to the exclusive thinking of Calvin. According to Calvin, the subject of religious tolerance is hindered by three areas, namely: the doctrine of God, ecclesiology (election rules in building God's Kingdom on earth), and hermeneutics (how to interpret the Bible in a positive light). For example, the doctrine of God. No human being today is moved from the contemplation of God as the universal God. What exists is Allah as the Heavenly Judge, because Allah is Most High. He is the Most High King and the Most High Judge. He who judges men against him sin. Calvin rejects the existence of a universal God, because of that God's doctrine cannot make humans tolerate. For
Calvin Allah is exclusive. Only through Jesus can humans be saved. So there is no salvation apart from Jesus. So, it turns out that not all of them can be tolerated. There are certain parts that can and there are certain parts that cannot. For example, the author has an exclusive position like Calvin, so for writers biblical tolerance can be done, if the problem concerns the doctrines of principles such as the doctrine of God, salvation, and the church then the writer cannot tolerate it.

4. Social Educators Jesus fed the people, healed the sick, raised the dead, and so on, all of which showed that Jesus cared for humans. Even the way of life of the early church is said: As for the multitude who had believed, they were of one heart and one soul, and no one said that anything from theirs was their own, but everything was theirs together (Acts 4:32). Also the purpose of choosing seven councilors to serve the poor, including care for widows (Acts 6: 1). It is absolutely clear that the Bible also teaches believers to live in a social life, taking care and helping out the difficulties faced by those in need. Not only fellow Christians but also non-Christians must be helped. And this is what Dahlan did to poor people in Yogyakarta, so we need to respect and imitate him. 


\section{Challenges For}

\section{Indonesian Educators}

Augustine said that basically humans have two desires, namely: First, they want to control their fellow humans, and second, they want to win in competition with each other. Because of these things, humans use the medium of war - tribal warfare, mafia violence, banditism, terrorist acts, village brawls, student brawls, racial riots, intergroup violence, rebellion, fights (fighting for energy); go to war (nerves, nerves) war not really fighting, new fear-scare, bluff.

The author sees that the nation's educators in this beloved country of Indonesia have certain goals (not sincere, loyal, and honest) in educating this nation. They have an attachment to the decisions or needs of the individual or the needs of the party they represent. So that what programs are carried out must be in line with the needs of individuals or parties. Here, it is very difficult to be able to develop any brilliant idea. So it is not surprising that many bright ideas are scattered but are not responded to or responded to by their respective moral erosion. Seeing this fact, the author invites the nation's educators to imitate what has been done by Ahmad Dahlan.

With his leadership to educate in a totalistas that is a compromise approach to character, creative and harmonious cooperation, peace-loving, and social, he has succeeded in developing the teachings of Islamic education in Indonesia. Why don't we follow up? If only all the leaders educate well, from the small groups to the highest in this country, follow Dahlan's example, then all the problems that are currently pressing on us, will slowly be resolved.

\section{CONCLUSION}

From the description above it can be concluded as follows: First, from the author's critical evaluation of Ahmad Dahlan's approach strategy for national educators, it can be concluded that the author agrees with the approach taken by Dahlan for national educators with the character Education approach, creative and harmonious cooperation. , peace-loving, and social, but for writers who still have to be careful is the tolerance approach. The author agrees that we must be tolerant as long as it conforms to the Bible's values and the author is intolerant of doctrinal principles such as the doctrine of God, salvation and the church. Second, if all leaders are educating the nation well, from number one in this country to the last number - following the example set by Dahlan, political, economic, security, polarization, religious tensions. 


\section{REFERENCES}

[1]. Alfian. Muhammadiyah: The Political

Behaviour of a Muslim Modernist

Organization Under the Dutch Colonialism.

Yogyakarta: Gajah Mada Press, 1969.

[2]. Anies, M.J. Boeah Congres Moehammadiyah Seperemat Abad. Yogyakarta: Hoofdeomite Congres Moehammadijah, 1936.

[3]. Asrofie, Yusron. Kiyai Ahmad Dahlan: Pemikiran dan Kepemimpinannya. Yogyakarta: Yogyakarta Offset, 1983.

[4]. Djaya, Tamar. Pustaka Indonesia: Orang-orang Besar Tanah Air. Bandung: G.Kolff \& Co., 1951.

[5]. Dods, Marcus. The City of God. Chicago: Encyclopaedia Britannica, 1973.

[6]. Dretke, James P. A Christian Approach to Muslims Reflections from West Africa. Pasadena: William Carey Library, 1979.

[7].Hadikusuma.Matahari-matahari

Muhammadiyah. Yogyakarta: Pesatuan, t.t.. Hadisiswaja, “K.H. Ahmad Dahlan”, Pandji Masyarakat, 1 No. 3 (1959).
[8]. Hallencreutz, Carl F. Kraemer towards [9]. Tambaran: A Study in Hendrik Kraemer's Missionary Approach. Uppsala: Alonqvist \& Wiksells, 1966.

[10]. Karim, M. Rusli Karim (ed.). Pendidikan Muhhammadiyah dalam Kritik dan Komentar. Jakarta: Rajawali, 1986.

[11]. Mulkhan, Abdul Munir. Menggugat Pendidikan Muhammadiyah. Yogyakarta: Fajar Pustaka Baru, 2000.

[12]. Peacock, James. Purifying the Faith. Menlo Park California: t.p., 1957.

[13]. Raffles, Tomas Stanford. The History of Java. London: Oxford University Press, 1965.

[14]. Sairin, Weinata. Gerakan Pembaruan Pendidikan Muhammadiyah. Jakarta: Sinar Harapan, 1995.

[15]. Sairin, Weinata. Gereja Agamaagama \& Pendidikan Nasional. Jakarta: Gunung Mulia, 1998.

[16]. Salam, Yunus. Riwayat Hidup K.H.A. Dahlan: Amal dan Perjuangannya. Jakarta: Departemen Pendidikan Muhammadiyah, 1968. 
[17]. Shibab, Alwi. Membendung Arus.

Bandung: Mizan, 1998.

[18]. Utomo, Bambang Ruseno. Hidup Bersama di Bumi Pancasila. Malang: Pusat Studi Agama dan Kebudayaan, 1993.

[20]. Yunan, M., dkk. Cita dan Citra Pendidikan Muhammadiyah. Jakarta: Pustaka Paji Mas, 1985.

[21]. Wadkins, Timothy H. "A Recipe for Intolerance: A Study of the Reasons Behind John Calvin's Approval of Punishment for Heresy,” JETS 26/4 (Desember 1983) 431441.

[22]. Warfield, Benjamin B. Calvin and Augustine. Philadelphia: The Presbyterian and Reformed Publishing Company, 1980. 
Journal Didaskalia

E-ISSN: 2621-8054

P-ISSN: 2622-1667 